\title{
5 \\ Mediating encounters through bodies and talk
}

\section{Tiffany Shellam}

Until recently, Australian exploration historiography has tended to cast and interpret the encounters between European explorers and Aboriginal people in terms of a dyadic, hierarchical relationship. This has strengthened the assumption that within the context of exploration, encounters are only ever between Indigenous people and Europeans, and only ever occur in a binary relationship. Yet exploration archives indicate that European explorers were well aware of the extra dynamic that the presence of a 'native aid', or 'intermediary', brought to encounters. They stress, for instance, their unfamiliarity with new environments, the limits of their languages, and the misunderstandings that sometimes arose between them and the Aboriginal people and communities they encountered. That they were surprised at all by this illustrates the ways in which explorers in the early nineteenth century were not always aware just how much complexity and regional diversity there was across Aboriginal Australia until they commenced travelling. The midshipman on Phillip Parker King's 1818 Australian hydrographic survey, John Septimus Roe, for instance, noted with surprise that Aboriginal

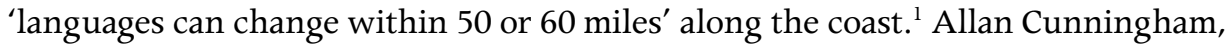

1 Roe, John Septimus, to William Roe, 6 June 1821, Mitchell Library, MLMSS 7964. 
the botanist on the same survey, registered difference between the expedition's intermediary, Boongaree, and Aboriginal people met along the way by referring to the latter as 'Stranger-Aborigines'. ${ }^{2}$

Scholars working on the exploration and colonisation of Africa and the Americas have, in recent years, highlighted the role of the go-between in the brokering between indigenous people and European newcomers, facilitating knowledge collection and valuable local information. Felix Driver's project with the Royal Geographical Society engaged with the 'hidden histories' of go-betweens in British exploration history by unearthing the experiences of indigenous people, local guides and interpreters who were part of exploration expeditions. ${ }^{3}$ Driver has recast intermediaries as central figures in exploration enterprises and has written their histories into the narrative of exploration and empire. Other scholars have focused on the lasting effect of go-betweens, from first encounters to possession and colonial settlement. For example, in Alida Metcalf's book Go-Betweens and the Colonization of Brazil, 1500-1600, she argues that 'go-betweens clearly took centre stage, for they were the means of communication in the middle grounds of encounters' ${ }^{4}$ Metcalf focuses on the 'opening up' that go-betweens enabled for the colonisers and themselves. In this triangular relationship that the presence of a go-between produced in encounters, Metcalf argues, 'they occupied an intermediate space between worlds where a boundary could become a borderland'. ${ }^{5}$ She also stresses that go-betweens were not neutral figures, they had 'complex and shifting loyalties that are difficult for modern historians to reconstruct' ${ }^{6}$ Australian scholar David Turnbull has also reflected on this idea of slippery loyalty, stating that '[g]o-betweens can both dissolve and create boundaries in the process of linking people, practices, and places in networks'. ${ }^{7}$ David Philip Miller, in his review of the book The Brokered World: Go-Betweens and Global Intelligence 1770-1820, referred to this renewed focus on intermediaries as 'history from between', a literature which he argues 'has presented a corrective to top down Eurocentric histories' in the same way that 'history from below' reacted against and sought to remedy the earlier political history's top down approach. ${ }^{8}$ Similarly, Dane Kennedy's recent comparative history Last Blank Spaces: Exploring Africa and Australia considers the role of overland guides and mediators in the British exploration of Australia and Africa in the nineteenth century. Discussing examples of intermediaries' autonomy in Australian exploration, Kennedy gives these men the identity

\footnotetext{
2 Cunningham. Allan Journal and Correspondence, 20 September 1816 - 7 May 1819, State Library of Victoria [hereafter Cunningham 1816-19]. 
of 'deracinated' figures, or 'marginal men', who had been ripped from their communities and 'forced by the circumstances of their estrangement to forge a new niche for themselves at the intersection of cultures' ${ }^{9}$ This chapter utilises this recent international scholarship on go-betweens in an attempt to highlight the role and effects of Australian Aboriginal intermediaries in British maritime expeditions along the north-west coast of the continent in the early to midnineteenth century.

Following Matthew Flinders' map of the continent, made during his circumnavigation in 1801, the British Admiralty, in concert with the Colonial Office, required hydrographic expeditions to fill in the missing parts of Flinders' coastal survey. The north-west and northern coasts of Australia needed the most clarification, and the surveys of 1818-22, captained by Phillip Parker King on the brig Mermaid and then Bathurst, and of 1837-41, captained by John Wickham on the Beagle, made successive visits to the north-west coast. Both expeditions took Aboriginal intermediaries on board and this meant that the north-west coast became a site of repeat visits and exchange between intermediaries, expedition members and Aborigines on shore.

This chapter will draw out some of these 'histories from between'. In particular, my aim is to elucidate the experiences of Boongaree, a Garigal man from Broken Bay, and Miago and Tommy, Nyungar men from the south-west of Western Australia, and to tease out the effects their presence had in engagements with Aboriginal strangers, as well as speculate about their own feelings about voyaging and mediating. We might ask: How did these people converse with strangers? What skills or techniques did they draw on? Were they directed about how to mediate by the crew, or free to broker in ways they desired? All three intermediaries had different experiences, and while their presence, to an extent, encouraged an 'opening up' of boundaries, it is the effect of the space of the expedition on their identities and histories that is most revealing. The episodes discussed below highlight the three intermediaries' techniques of brokering, with particular attention given to the use of their bodies and their talk, which I then discuss in further detail at the end.

9 Kennedy 2013: 166. 


\section{Boongaree}

Boongaree, often referred to as Bungaree, was a Garigal man, probably from the Broken Bay-West Head group to the north of Port Jackson, and born around 1775. ${ }^{10} \mathrm{He}$ has become one of the most famous and iconic of all go-betweens in early colonial Australia, with a reputation as a man who moved with ease between the Aboriginal world and that of the newcomers. 'His activities in Port Jackson as a self-appointed Aboriginal ambassador' and welcomer of ships has been the topic of much discussion and myth-making. ${ }^{11}$ However, besides the work of Bronwen Douglas and David Turnbull, who have written about Boongaree's mediation during Flinders' circumnavigation in 1803, historians have generally placed little emphasis on what is arguably Boongaree's most important role: intermediary on the maritime expeditions of Matthew Flinders and Phillip Parker King. ${ }^{12}$ Instead, as David Hansen has argued, Boongaree's legacy was framed in the decade before his death (1820-30) through anecdotes and many portraits conveying the image of him as an 'eccentric low life'. ${ }^{13}$ Hansen writes: 'He is not remembered as the explorers' aide, the first Aborigine to circumnavigate Australia ... No he is remembered as a comic metonym of early colonial Sydney: mimic, beggar, drunk. ${ }^{14}$ Here I will examine what Boongaree did as a 'native aid' on board the Mermaid.

From December 1817 to July 1818, Boongaree joined the Australian hydrographic expedition captained by Phillip Parker King. While Boongaree did not keep a written record of his own experience of voyaging (and was probably illiterate), some of the crew recorded details about his experience and described him in their journals and letters. The expedition's botanist, Allan Cunningham, referred in his journal to Boongaree affectionately as 'our friend', 'our witty friend' or 'our Native chief'. ${ }^{15}$ Prefacing Boongaree's name with 'ours' placed him in possession of the expedition; it also served to set up a dichotomy between Boongaree and other Indigenous people they encountered, and also a triangular relationship which included the crew, Aboriginal strangers on shore and Boongaree inbetween. By contrast, the midshipman, John Septimus Roe, made only brief and disapproving, although revealing, comments of Boongaree in his letters home to his father, while King wrote of him with a mixture of frustration and gratitude. The encounters discussed here will help to explain why.

10 In the explorers' texts that I am using, his name is spelt Boongaree, however, he was also commonly recorded as Bungaree, Bongree, Bongary, and largely known as Bungaree today.

11 See Smith 1992.

12 Douglas 2007: 18; Turnbull 2009.

13 Hansen 2007: 30.

14 Hansen 2007: 30.

15 Cunningham 1816-19: 25 January 1818, at King George's Sound; 25 February 1818, Enderby Island. 


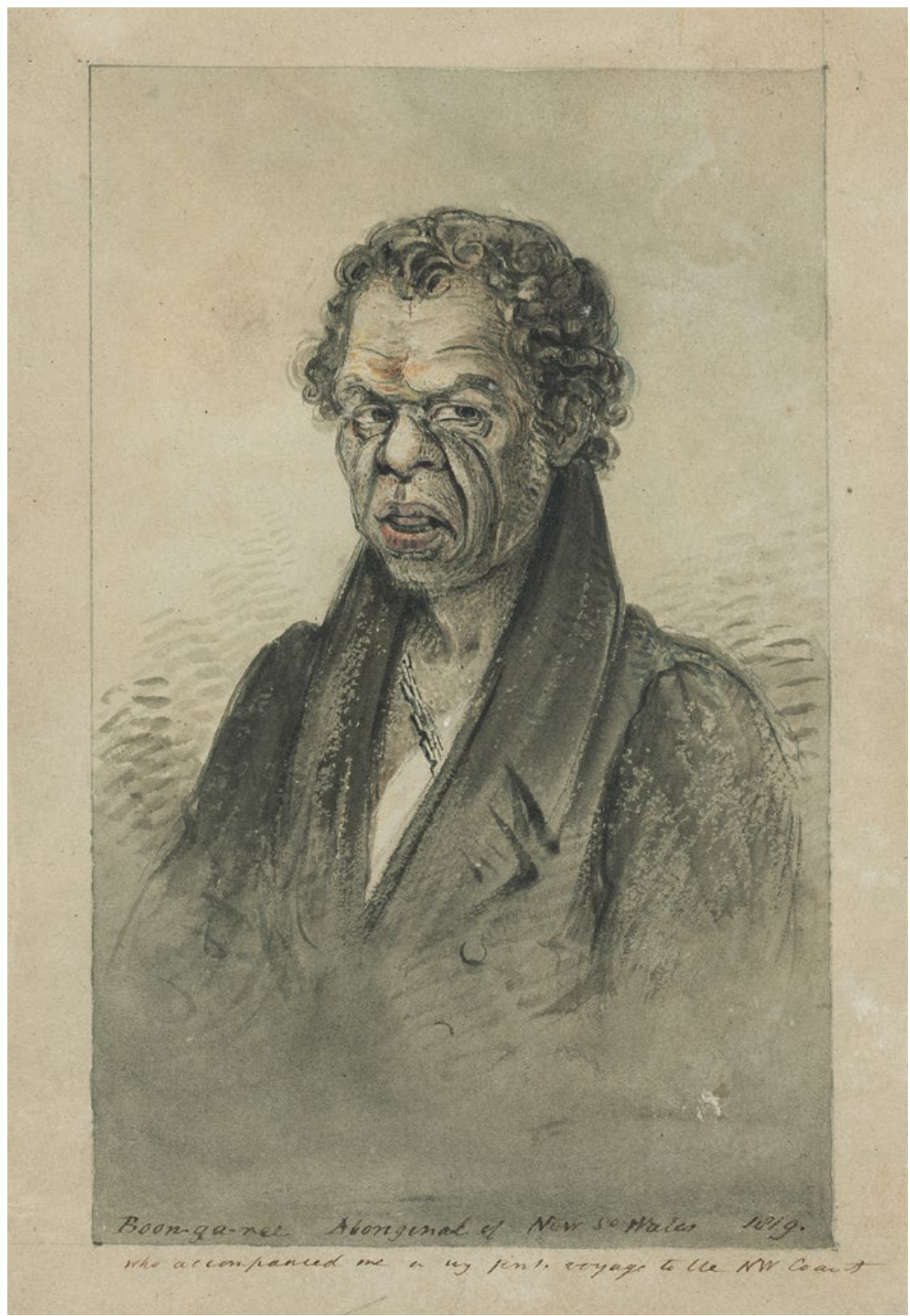

Figure 5.1 Phillip Parker King, 'Boon-ga-ree Aboriginal of New So. Wales 1819 who accompanied me on my first voyage to the NW Coast'. Source: Phillip Parker King, album of drawings and engravings, 1802-1902, PXC 767, Mitchell Library, State Library of New South Wales. 
On 26 February 1818, the Mermaid was sailing close to the islands of Dampier's Archipelago, near present-day Karratha, when three Jaburara men were seen in the water 'floating on logs' ${ }^{16}$ Steering their course directly for these men, a jolly boat was lowered and Frederick Bedwell, the second midshipman, pulled one of the men by his hair into it. ${ }^{17}$ King wrote that this man was 'unwilling' to be brought on board the ship until 'Boongaree showed himself to him when he obtained a little more confidence and he allowed himself to be conducted over [the side] and [into this vessel]'. A conversation between Boongaree and this man must have been attempted, because Cunningham recorded that 'he occasionally made signs towards the land, and talk'd but his language was neither understood by Boongaree our Port Jackson native or ourselves' ${ }^{18}$

This kidnapped man was clearly unsettled. The crew tried to put him at ease by giving him food and gifts, but King remarked that this man 'looked round discontented [appeared anxious] and with a sort of inquiry when Boongaree was away from him and on his return he appeared pleased'. ${ }^{19}$ Cunningham likewise wrote that this man 'took much notice of Boongaree, who had reluctantly at our persuasion, strip'd and exhibited a scarified body'. The Jaburara captive had scars too, on his breast and stomach. Cunningham referred to Boongaree's nudity in the presence of this captive as a 'counterpart of the strangers', linking their naked 'native' bodies.

Boongaree was also a key figure when the crew went ashore to meet with the 30 Jaburara people who had collected on the beach later that day. The man who had been kidnapped earlier soon noticed Boongaree and 'pointed him out to his Comrades, who addressed themselves to him, wishing him more particularly to land with them' ${ }^{20}$ King also added: 'they were all much struck with Boongaree's appearance and appeared to be very anxious to talk with him but for Boongaree who upon all occasions forgets his native tongue addressed them in Broken English - it is of little consequence for he does not understand one word uttered by them and therefore he would have been misunderstood in English as in his Port Jackson language.' But the effect of Boongaree's presence was clear. King explained: 'When Boongaree opened his mouth to speak they were all quite silent awaiting for his answers to the question which every one was putting to him.' ${ }^{21}$ Several other encounters occurred over the following days; at each meeting Boongaree removed his clothes. As the crew departed Dampier's Archipelago, King wrote that 'Boongaree was made very much of' by

16 King, Phillip Parker December 1817-July 1818, 'Remark Book', Mitchell Library, MLMSS.5277 [hereafter King 1817-18]: 26 February 1818.

17 King 1817-18: 26 February 1818.

18 Cunningham 1816-19: 26 February 1818.

19 King 1817-18: 26 February 1818.

20 Cunningham 1816-19: 26 February 1818.

21 King 1817-18: 26 February 1818. 
the Jaburara who 'appeared quite delighted to find his shoulders scarified like their own he always spoke to them in Broken English - He however, is of great use to us ... on the appearance of a Black man being with us [has] given them a confidence what it could be difficult otherwise to instill' ${ }^{22}$

From this brief episode it is possible to see the ways in which Boongaree's presence was crucial in these encounters, as he was looked to and depended upon by explorers and locals alike. He was sought out by the Jaburara, who are described as being less anxious in his presence. And King and Cunningham were aware of and grateful for Boongaree's usefulness in encouraging a mutual confidence between strangers. As I will discuss in more detail, it was the points of similarity rather than strangeness that were emphasised in these encounters between Aboriginal people.

\section{Miago}

Miago was a Nyungar man from the Upper Swan country to the north of the Perth township, and by 1833 was well known to colonial settlers at Swan River. He was represented in the local newspapers as a mediator between the Aboriginal groups living around Perth and described by colonial observers as a 'messenger of peace' and an 'ambassador'. He acted as broker between the Swan River groups, Governor Stirling and the Pinjarra group soon after the Pinjarra massacre in $1834 .{ }^{23}$ As well as his mediating skills, he was considered a useful tracker and guide, assisting survey parties and tracking lost settlers in the bush. ${ }^{24}$

In planning for the Beagle's Australian survey, the Admiralty encouraged its captain, John Wickham, to 'hire, at a low rate, some person acquainted with the dialects of the natives, which you are subsequently to visit, and with whom it will be essential to be on friendly terms' ${ }^{25}$ John Septimus Roe, who had been midshipman on King's earlier expedition, had travelled with Miago overland to King George's Sound from Swan River in 1835, and he advised the next maritime surveyor of the north-west coast to take Miago on board the Beagle in 1837. Lieutenant John Lort Stokes, Wickham's assistant surveyor, wrote that:

22 King 1817-18: 26 February 1818.

23 Perth Gazette, 3 January 1835; CSR 37/178, 230 State Records Office of Western Australia [hereafter SRO WA]; Perth Gazette, 29 March 1835.

24 CSR 29/157-9, SRO WA.

25 F. Beaufort, 8 June 1837, printed in Stokes 1846, vol. 1. 
Among the many useful hints, for which we were indebted to Mr Roe, was that of taking a native with us to the northward; and accordingly, after some trouble, we shipped an intelligent young man, named Miago; he proved in some respects, exceedingly useful, and made an excellent gun-room waiter. ${ }^{26}$

In Stokes's published narrative of this voyage, he described how he questioned Miago about particular aspects of Aboriginal culture on which he wanted clarification. In the contained space of the expedition, Miago became the archetype or axis upon which all other Aborigines encountered were compared or contrasted.

Unlike the east coast intermediary Boongaree, who probably had little or no prior knowledge of Aborigines of the north-west before travelling there, Miago had stories and deep knowledge of the northern Aboriginal groups of the west coast. Like many south-western Aboriginal people in this period, Miago feared his northern neighbours, the Waylo or weel men, who were considered to be physically large and violent by the southerners. This, I suggest, contributed to Miago's belief that even far-distant north-westerners were men to be feared, and was perhaps the cause of the 'trouble' that Stokes referred to in coaxing Miago to join the expedition. As Stokes noted, Miago 'evidently holds these north men in great dread ... They are, according to his account, "Bad men - eat men - Perth men tell me so: Perth men say, Miago, you go on shore very little, plenty Quibra men [men of the ship] go, you go."' Stokes's rendition suggests that Miago used the explorers as his mediators when they encountered these northern men, a position he was advised to take by his countrymen. ${ }^{27}$ Stokes further recorded: 'These instructions' to stay close to the ship and the crew 'appear to have been very carefully pressed upon him by his associates, and certainly they had succeeded in inspiring him with the utmost dread of this division of his fellow countrymen' ${ }^{28}$

The Beagle was anchored at Cape Villaret, near present day Broome, on 18 January 1838. When Miago heard that Aborigines had been sighted on shore, he was 'delighted that these blackfellows, as he calls them, have no throwing sticks' ${ }^{29}$ Of his landing the following day, Stokes further recorded Miago's fear:

Miago had accompanied this party on shore, though he evidently showed no great devotion to the deed. They said he watched everything, aye, every bush, with the most scrutinising gaze: his head appeared to turn upon a pivot, so constantly was it in motion..$^{30}$

26 Stokes 1846, I: 58.

27 Stokes 1846, I: 74-75.

28 Stokes 1846, I: 75.

29 Stokes 1846, I: 74.

30 Stokes 1846, I: 78. 
A few days later at Beagle Bay, Stokes recorded an encounter with a group of Nyul Nyul people, and their reaction to Miago:

Their speech was shrill and quick, perfectly unintelligible to our friend Miago, who seemed greatly in fear of them: they seemed astonished to find one apparently of their 'own clime, complexion, and degree' in company with the white strangers, who must have seemed to them a distant race of beings; nor was their wonder at all abated when Miago threw open his shirt, and showed them his breast curiously scarred after their fashion ... as a convincing evidence that he, though now the associate of a white man, belonged to the same country as themselves. ${ }^{31}$

It is worth remembering the possibility that go-betweens, rarely neutral, influenced the power dynamics at play in the relations between the Aboriginal and European worlds. 'There is a further dimension of power' in the triad relationship, as Alida Metcalf has written: 'go-betweens may exploit their positions for their own benefit', because he or she is indifferent to the outcome. ${ }^{32}$ According to Stokes, Miago frequently expressed a desire to kidnap an Aboriginal woman from the north-west to take back to Swan River. Stokes believed that she would be tangible evidence to his kin of his far travels. ${ }^{33}$ This theme of evidence of experiences - a desire by Aboriginal intermediaries to bring evidence of their new knowledge and experience of travel back to their countrymen - is apparent in other exploration accounts in Western Australia. For instance, when Manyat, a Nyungar man from King George's Sound, travelled beyond his known geographic domain with colonial surgeon and naturalist Alexander Collie in 1833, he brought back bark from trees he had hitherto not seen to show his countrymen how far he had travelled. ${ }^{34}$ Miago's desire to kidnap a woman also reveals that Miago had in mind the expedition's aftermath: he was thinking about his return home, and perhaps already anticipating the reception he might receive from his countrymen. Miago certainly used the crew to his own advantage, whether placing them in a mediating position for him in his fears of the northern strangers or using his in-between position for gain in quite specific ways. However, whether he really desired to take a woman, or, as Stokes suggested, it was just bravado, Miago's fear outweighed his desire: 'all his boasting', Stokes wrote, 'about killing some of them and taking one of their women as proof of his prowess, back to Perth, failed to concern. ${ }^{35}$ At Hanover Bay, much to Miago's protest, the crew went ashore to meet a group of Worora men. These men very closely examined the heroic Miago, who submitted to be handled by these much dreaded northern men

with a very rueful countenance, and afterwards construed the way in which one of them had gently stroked his beard, into an attempt to take him by the 
throat and strangle him! An injury and indignity which, when safe on board, he resented by repeated threats, uttered in a sort of wild chant, of spearing their thighs, backs, loins, and indeed, each individual portion of the frame. ${ }^{36}$

While Miago's fear is prominent in Stokes's account, the episode suggests other interpretive possibilities. It is clear, for instance, that these encounters were also intimate: a Worora man had 'gently stroked' Miago's beard, even if he later chose to render it an intrusive gesture.

Miago may have benefitted from his fluid position as go-between, but he was also frequently described as being homesick and unsettled at sea. Being away from kin may have been difficult for some intermediaries. On their return, journey Miago was, according to Stokes, increasingly impatient for Swan River and would stand by the gangway singing mournful songs. Stokes recorded:

Miago, who was as anxious as any one on board for the sight of his native land. He would stand gazing steadily and in silence over the sea, and then sometimes, perceiving that I watched him, say to me 'Miago sing, by and by northern men wind jump up:' then would he station himself for hours at the lee-gangway, and chant to some imaginary deity an incantation or prayer to change the opposing wind. I could never rightly learn to whom this rude melody was addressed; for if any one approached him near enough to overhear the words, he became at once silent; but there was a mournful and pathetic air running through the strain, that rendered it by no means unpleasing; though doubtless it owed much of its effect to the concomitant circumstances. ${ }^{37}$

While Stokes suggests Miago's songs were mournful and evidence of his homesickness, it is also clear that some of his songs were intended for the northern men he had met with. The explorer and later governor George Grey, who was picked up by the Beagle on the north coast, recorded in his journal that '[i]f a native [is] afraid, he sings himself full of courage; in fact under all circumstances he finds aid and comfort from a song' ${ }^{\prime 3}$ Grey also described the song that Miago's mother sang constantly during his absence at sea: 'ship bal win-jal bat-tar-dal gool-an-een', which he translated as 'whither is that lone ship wandering'. ${ }^{39}$ On Miago's safe return, another song was composed by a Nyungar man after hearing the stories about his adventures at sea. ${ }^{40}$ The lyrics go: 'Unsteadily shifts the wind-o, unsteadily shifts the wind-o, The sails-o handle, the sails-o handle-ho.' Martin Gibbs has written about the Nyungar songman and whaler Nebinyan, and how 'the novel experience of whaling'

36 Stokes 1846, I: 99.

37 Stokes 1846, I: 221-222.

38 Grey 1841: 404.

39 Grey 1841: 409-410.

40 Grey 1841: 10. 
provided him with 'material to translate into song and dance, and consequently further facilitated his rise in standing within ... Nyungar society' ${ }^{41}$ Shipboard experience gave Miago material for a story-song too.

Boongaree also utilised songs during his expeditioning. Rather than a medium to recount his adventures, his singing was a mediating technique. When meeting with Undambi people at Skirmish Point while travelling with Matthew Flinders in 1791, the Undambi sang and Boongaree reciprocated with a song of his own. ${ }^{42}$ Flinders wrote that the Undambi 'singing was musical and pleasing', but 'the song of Bong-ree', which he gave at the conclusion of theirs, sounded barbarous and grating to the ear and 'annoyed his auditors'. Both Flinders and Stokes disliked the sound of their intermediaries' singing, but, perhaps, they were missing the meaning of this music. Rather than music to be enjoyed, it was it seems an improvised, and unpractised or unrehearsed, technique required of them in the context of their brokering. ${ }^{43}$

\section{Tommy}

In 1839 Tommy replaced Miago on the Beagle's voyage for a successive expedition to the north-west. His Nyungar name was Yee-lal-nar-nap - but the crew called him Tommy. He was a young man who had joined the expedition with his 'mother's consent'. Mr Pasco, a master's mate, wrote that 'Poor Tommy soon felt homesick or mammy-sick, for I noticed [him] one evening under the lee of the spanker crying. "What are you crying about, Tommy?" I inquired. "Cos my mudder cry now, I know, so I cry." ${ }^{44}$ Like Miago, Tommy also feared the northern men, and his encounters too were shaped by his history and knowledge of them. After Fitzmaurice, who had taken a whaler to survey the coast, had been confronted by Aboriginal people on shore and had chosen to retreat rather than use his guns, Stokes made note of Tommy's bravery:

It was of much the same complexion as that of Miago; and he threatened magnanimously to inflict the most condign punishment on the fellows who opposed Mr Fitzmaurice's landing. He had a strong impression that these northern people were of gigantic stature; and in the midst of the silent and gaping interest

\footnotetext{
41 Gibbs 2003: 12.

42 Collins 1804: 512.

43 The explorers themselves were not shy of improvising with song and dance when they were in a dangerous encounter with Aborigines. Keys and Fitzmaurice from the Beagle voyage 'danced for their lives' and sang a 'Scottish reel' when faced with 'hostile' Aborigines at Adam Bay near Port Essington. Stokes recorded: 'No one could recall to mind, without laughing, the ludicrous figure necessarily cut by our shipmates, when to amuse the natives they figured on the light fantastic toe; they literally danced for their lives.' Stokes 1846, II, frontispiece. 44 Pasco 1897: 112.
} 
with which he listened to Mr Fitzmaurice's account of his adventure, the words 'big fella' often escaped from his lips; and he appeared quite satisfied when assured that his opinion was correct. ${ }^{45}$

Such stories about the north-west coast being inhabited by 'giants' or 'big men' were not specific to southern Aboriginal groups. Shino Konishi has written about French descriptions of Aboriginal people at Shark Bay in 1803. François Péron, the naturalist on board Nicholas Baudin's scientific expedition, recorded the 'extraordinarily big, strong men' who were 'like giants' that had been seen by their sailors when they went turtle fishing. ${ }^{46}$

Pasco also recorded Tommy's impression of Coepang in Timor and an encounter that took place there. At Coepang,

members of the monkey tribe were numerous. There are also a number of Chinese engaged in business on the island. Both monkeys and Chinamen were novelties to Tommy, but from seeing the Chinese wear tails [tail shirts?], he thought there must be some connection between man and monkey. Taking him into a Chinese store, the China boy, who had never seen an Australian aboriginal before, said to Tommy, 'You go away, you eat him man.' 'No', said Tommy, very indignantly, 'my not yeat him man, but you yeat him monkey, look you tail'. ${ }^{47}$

\section{Mediating sameness and strangeness}

In thinking about the experience of these Aboriginal men and their border crossings in the context of maritime exploration it is obvious that their bodies and their talk were crucial vehicles for, as well as points of, connection during meetings with Aboriginal people who were strangers to them. According to Phillip Parker King, Boongaree's skill as 'native aid' was inseparable from his body. His physique, his clothes - or absence of them - were crucial aspects of his presence and effect in encounters. His nudity was frequently commented upon in the crews' journals, when they regularly drew connections between the removal of his clothes and the success of encounters. Indeed, soon after leaving Port Jackson in December 1817, the expedition met with some Aborigines on the east coast at Twofold Bay. King was frustrated on this occasion that Boongaree had refused to remove his elaborate English attire when meeting Aborigines there. The failed communication at this site, King thought, was due to Boongaree's clothes, which had been given to him especially for the 
expedition and might explain why he was loath to remove them so early on in the journey. He was, according to King, 'looking quite fierce with a new blue jacket and trousers, a red frock and cap'. ${ }^{48}$

King recognised the language of the body in human encounters. He had done enough pantomiming himself to know that the body, more than words, was an effective way to communicate with strangers. He recognised too that Boongaree's body - his skin colour, physical features and decoration - would speak a language that his white, clothed body could not. For all the differences between Boongaree and the other Aboriginal people they met, their bodies could be a point of sameness or at least similarity.

Yet King still yearned for the security of language, commenting each time in disappointment when Boongaree used broken English to speak with 'Strangers', and voicing his frustration when it was not possible to record a vocabulary. Likewise, at Beagle Bay, Miago, according to Stokes, 'very sagaciously addressed' the Nyul Nyul people

in English; shaking hands and saying, 'How do you do?' and then began to imitate their various actions, and mimic their language, and so perfectly did he succeed that one of our party could not be persuaded that he really understood them; though for this suspicion I am convinced there was in truth no foundation. ${ }^{49}$

Boongaree and Miago's use of broken English rather than their native language is revealing. As David Turnbull suggests, it was 'the improvised resort of a go-between trying to create an auditory common ground, but relying on the language he had acquired during an earlier boundary crossing.$^{50}$ But it was precisely these acquisitions that expedition leaders sometimes wished their intermediaries to downplay. While explorers were often well aware of the strangeness between their guides and the Aboriginal locals, they also, as the episodes above attest, attempted on many occasions to render these people more familiar to each other: encouraging Boongaree to forget his broken English, remove his clothes - to be an 'authentic Aborigine' and not the 'civilised native' he had become.

Grace Karskens recently pointed out the strategic use of clothes by Aborigines in colonial Sydney, overturning earlier historiographies that interpreted Aborigines wearing clothes as a sign of degradation and cultural disintegration. ${ }^{51}$ In these encounters we see something else: Boongaree, content in his European clothes, was encouraged - sometimes coerced - to remove them, while some of

48 King 1817-18: 26 December 1817.

49 Stokes 1846, I: 91.

50 Turnbull 2009: 415.

51 Karskens 2011. 
the Aborigines he encountered, such as the captive at Dampier's Archipelago, were dressed, their presentation altered then applauded, when they came on board the ship. European clothing was practical and meaningful for Boongaree and being forced to remove them may have chagrined him. Yet there were times when he was content to remove his clothing of his own volition. In settlements 'it was frequently remarked upon by settlers that Aborigines removed their European clothes when they went back to their own camps' ${ }^{52}$ Boongaree visited Frenchman Rene Lesson in 1822 on his way to corroborees. Lesson contests that Boongaree 'appeared a transformed man. The coat and plumed hat were gone, his powerful body was dusted with red ochre and painted with red and white clay, his canoe filled with spears and clubs. ${ }^{53}$ Karskens persuasively shows that for Aboriginal people in colonial Sydney, European clothing was meaningful, and rather than a symbol of degradation, Aboriginal people wore clothes in distinctive ways. There was, she argues, an Aboriginal style of dressing - jacket with the collar turned up, and without a shirt, keeping the cicatrices on the chest visible. This Aboriginal mode, Karsken argues, was established in the mid-late 1790s. ${ }^{54}$

It was not simply black naked bodies that were important in these exchanges, but the inscriptions that they revealed. Both Boongaree and Miago were initiated men, having gone through the process of ritual scarification. These 'deliberatelymade cuts and keloid cicatrices engrave social and cultural meaning and brand bodies as inextricably part of the social collective'. As Anna Haebich has written, they speak of inclusion of membership; projecting affiliated lineage on identity within a social hierarchy. ${ }^{55}$ Boongaree had been inscribed by both his Aboriginal and colonial worlds. He was the first Aborigine to be given a king plate. Historians have read these metal gorgets, hung around the necks of designated wearers, as a form of colonial branding or labelling. Such inscriptions identified people like Boongaree as useful, worthy individuals; they also could be read by other settler-colonials as a badge of protection against frontier violence. As Ray Evans has written: 'Bearing the "imprint of the master's control" and testifying to the wearers' deracination, they eradicated one identity and imposed another. ${ }^{56}$ For contemporary Aboriginal people, as Kate Darian-Smith has argued, breastplates remain emotionally ambiguous 'Aboriginal-European' objects, reflecting both 'imperial oppression and violence' as well as 'Aboriginal adaptation and resilience' ${ }^{57}$ However, I would suggest that Boongaree not only wore his king plate like his English dress - with pride - he also used it and

\footnotetext{
Karskens 2011: 26.

Karskens 2011: 26.

Karskens 2011: 17.

Haebich 2008: 3.

Quoted in Van Toorn 2008: 233.

Darian-Smith 2015: 55.
} 
the status it brought to benefit him in the fairly crazy and rapidly shifting context of colonial life in Sydney. Rather than losing an identity, he added to his existing one.

Was this push and pull between Aboriginal and European worlds something that Boongaree was accustomed to and part of a survival strategy? Some explorers utilised the suspended space of the expedition - on board a ship, away from the go-betweens' country - to conduct experiments in civilisation. All crew members commented on the rapidity with which Boongaree and Miago went back to their uncivilised ways at the end of the expedition, suggesting their failure to convert. Boongaree did not rejoin King's expedition as he had cultural obligations to fulfil, yet the crew represented this as a step backwards and an abandonment of the expedition. As Roe, the midshipman, stated: 'he had secreted himself in the Woods'.$^{58}$ Miago's much anticipated return to Swan River is constructed by the expeditioners as a crisis of identity. The master's mate, Benjamin Francis Helpman, found it amusing, representing it in the following way:

A great piece of fun! Miago the New Hollander, went ashore. He had one of the Captain's old dress coats; a gold-laced cap with feathers in it; my old sword and belt, with a pair of new trowsers. He looked more like a stuffed monkey. On landing he was distant with his old friends and brothers. He would not allow them to kiss him, because he said they were not 'wilgayed'. And the cream of the joke is, he would not speak his own language, but would persist in speaking English, although they did not understand a word of what he said..$^{59}$

Soon, Stokes records, he rejoined his kin and went back to his 'uncivilised' ways, and when asked to rejoin the expedition he decided to remain at home with his wife. Stokes describes it in the following way:

We were considerably amused with the consequential air Miago assumed towards his countrymen on our arrival, which afforded us a not uninstructive instance of the prevalence of the ordinary infirmities of our common human nature, whether of pride or vanity, universally to be met with both in the civilized man and the uncultivated savage. He declared that he would not land until they first came off to wait on him ... During the time that Miago was on board we took great pains to wean him from his natural propensity for the savage life by instilling such information as his untutored mind was capable of receiving, and from his often expressed resolutions we were led to hope a cure had been effected; great was our disappointment then on finding that in less than a fortnight after our arrival,

58 Roe, John to William, 6 June 1821, MLMSS 7964.

59 Christie 1943-44: 13. 
INDIGENOUS INTERMEDIARIES

he had resumed his original wildness, and was again to be numbered amongst the native inhabitants of the bush. To us he had been the source of great mirth, by the absurd anecdotes he sometimes related about his countrymen. ${ }^{60}$

Later, George Grey commented on this tension for Miago, comparing the 'apparently perfectly civilised' native he had first met on board the Beagle who 'waited at the gun room mess, was temperate (never tasting spirits), attentive, cheerful, and remarkably clean' with the 'savage, almost naked [man] painted all over ... (who) had been [involved] in several murders' ${ }^{61}$

\section{Conclusion}

David Phillip Miller has warned against too much focus on intermediaries. This, he argues, could lead 'us to neglect the larger forces within which they operated'. He states that it is 'easy in our fascination' with these colourful, puzzling characters to overstate their agency. ${ }^{62}$ Miller is right to urge us to find a balance between the mythic explorer-hero narrative from which intermediaries were excluded, and an 'add guides and stir approach'. By conceptualising the expedition as an experiment undertaken by both intermediaries and explorers, we can include in our analyses the colonial and imperial contexts in which Boongaree and Miago were operating, as well as allow space for an exploration of the experiments and improvisational techniques utilised by them with their bodies and their talk when meeting with strangers. It is possible to see these techniques as part of an emerging repertoire for Aboriginal intermediaries as they found themselves to be momentarily key protagonists in slippery, triangular relationships.

\section{References}

Christie, E.M. 1943-44. Being Extracts and Comments on the Manuscript Journals of Benjamin Francis Helpman of H.M. Sloop 'Beagle' 1837-38-39-40, Extract from Proceedings 1943-1944, Royal Geographical Society of Australasia South Australian Branch Incorporated, Adelaide, 1-59.

Collins, David 1804, An Account of the English Colony in New South Wales, from its first settlement in January 1788, to August 1801, second edition, T. Cadwell and W. Davies, London.

60 Stokes 1846, I: 226-229.

61 Hordern 1989: 88.

62 Miller 2011: 613. 
Cunningham, Allan Journal and Correspondence, 1816-19, 20 September 1816 - 7 May 1819, Colonial Secretary's Office Records, Australian Joint Copying Project, GM47, Reel no.6034, State Library of Victoria.

Darian-Smith, Kate 2015, 'Breastplates: re-enacting possession in North America and Australia', in Conciliation on Colonial Frontiers: Conflict, Performance and Commemoration in Australia and the Pacific Rim, Kate Darian-Smith and Penelope Edmonds (eds), Routledge, New York, 54-74.

Driver, Felix and Lowri Jones 2010, 'Hidden Histories? Local knowledge and indigenous agency in the history of geographical exploration', Proceedings of the 14th International Conference of Historical Geographers, Kyoto University Press, Kyoto.

Douglas, Bronwen 2007, 'The lure of texts and the discipline of praxis: crosscultural history in a post-empirical world', Humanities Research XIV(1): 11-30.

Gibbs, Martin 2003, 'Nebinyan's songs: an Aboriginal whaler of south-west Australia', Aboriginal History 27: 1-15.

Grey, George 1841, Journals of Two Expeditions of Discovery in North-West and Western Australia, during the years 1837, 1838 and 39, in two volumes, vol. II, The Echo Library, Middlesex.

Haebich, Anna 2008, 'Marked bodies: a corporeal history of colonial Australia', Borderlands e-journal 7(2).

Hansen, David 2007, 'Death dance' [A salute to Bungaree of the Carigal clan of the Kuringgai tribe from Broken Bay, NSW.], Australian Book Review 290(April): 27-32.

Hordern, Marsden 1989, Mariners be warned: John Lort Stokes and HMS Beagle in Australia, 1837-1843, Melbourne University Press, Carlton, Vic.

Karskens, Grace 2011, 'Red coat, blue jacket, black skin: Aboriginal men and clothing in early New South Wales', Aboriginal History 35: 1-36.

Kennedy, Dane 2013, The Last Blank Spaces: Exploring Africa and Australia, Harvard University Press, Cambridge, MA.

King, Phillip Parker December 1817-July 1818, 'Remark Book', Mitchell Library, MLMSS.5277, item 1, 1-103.

Konishi, Shino 2008, "Inhabited by a race of formidable giants": French explorers, Aborigines and the endurance of the fantastic in the great south land, 1803', Australian Humanities Review 44(March): 7-22. 
INDIGENOUS INTERMEDIARIES

Metcalf, Alida C. 2005, Go-Betweens and the Colonization of Brazil: 1500-1650, University of Texas Press, Austin.

Miller, David Philip 2011, 'History from between', Technology and Culture 52(3): 610-613.

Pasco, Crawford 1897, A Roving Commission: Naval Reminiscences, George Robertson and Company, Melbourne, Adelaide and Sydney.

Roe, John Septimus, Letter to his brother William Roe, off Cape Capricorn on east coast of Australia, 6 June 1821. Series 05: John Septimus Roe letters, the Australian survey completed: the voyage of the Bathurst 2 June $1821-$ 1 June 1823, Mitchell Library, State Library of New South Wales, MLMSS 7964 / vol. 5 (Safe 1 / 468), Item 160.

Shellam, Tiffany 2010, “"Manyat's sole delight: travelling knowledge in Western Australia's south west, 1830s', in Transnational Lives: Biographies of Global Modernity, 1700-Present, Desley Deacon, Penny Russell and Angela Woollacott (eds), Palgrave Macmillan, Basingstoke, England, 121-132.

Smith, Keith Vincent 1992, King Bungaree: A Sydney Aborigine Meets the Great South Pacific Explorers: 1799-1830, Kangaroo Press, Kenthurst, NSW.

Stokes, John Lort 1846, Discoveries in Australia; with an account of coasts and rivers explored and surveyed during the voyage of H.M.S. Beagle in the years 1837-38-38-39-40-41-42-43, T. \& W. Boone, London, 2 vols.

Turnbull, David 2009, 'Boundary-crossings, cultural encounters and knowledge spaces in early Australia', in The Brokered World: Go-Betweens and Global Intelligence 1770-1820, Simon Schaffer, Lissa Roberts, Kapil Raj and James Delbourgo (eds), Science History Publications, Sagamore Beach, MA, 387-428.

Van Toorn, Penny 2008, 'Slave brands or cicatrices? Writing on Aboriginal skin in Tom Petrie's Reminiscences of early Queensland', Biography 31(2): 223-244. 
This text is taken from Indigenous Intermediaries: New Perspectives on Exploration Archives, edited by Shino Konishi, Maria Nugent and Tiffany Shellam, published 2015 by ANU Press, The Australian National University, Canberra, Australia. 